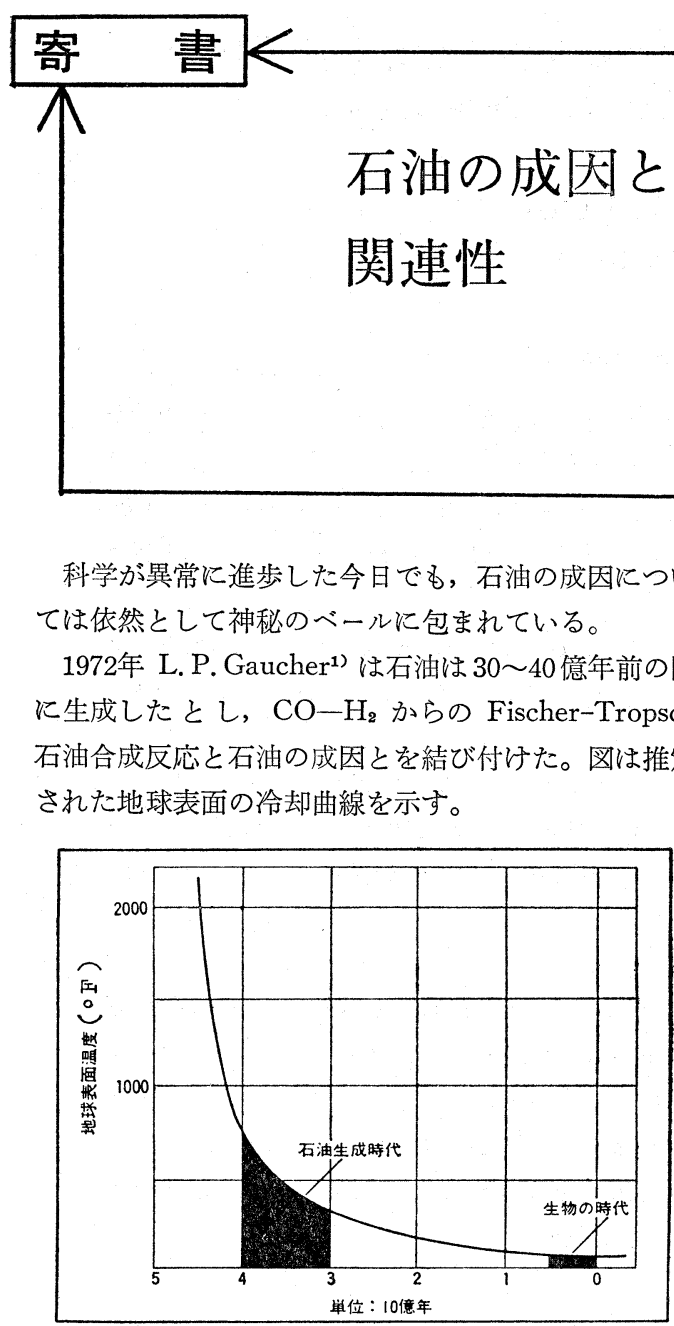

図 1 地球の経時冷却図

月着陸の成功によって, 月と地球とは㹬同じ年代 の45億年前に生成し，その後 5 ～15億年たった 40〜30 億年前の地表の温度はそれぞれ約 $390^{\circ} \mathrm{C}$ 和よび $180^{\circ} \mathrm{C}$ と 考えられている。そして地球を取巻く雲团気は $\mathrm{CO}_{2}$, $\mathrm{H}_{2}$ 打よびスチームで, $\mathrm{N}_{2}$ は少量存在したが $\mathrm{O}_{2}$ は なかったとされている。

上記の $180 \sim 390^{\circ} \mathrm{C}$ は一応 Fischer-Tropsch 反応に 適合した温度で，また $\mathrm{CO}_{2}-\mathrm{H}_{2}$ は Shift 反応によっ て $\mathrm{CO}_{2}-\mathrm{CO}-\mathrm{H}_{2}$ の混合ガ スとなることは比較的容 易である。一方地球表面には，触媒として好適な $\mathrm{Ni}$, $\mathrm{Co}, \mathrm{Fe}$ が存在したことは間違いなく, これらの触媒 作用によって生成石油の蒸気は地球の表面を包み, 地 表の温度降下によって Petroleum rain となって地球

三菱電機(株)中央研究所 枚方市走谷1-18-13
表面に落下したと Gaucher は考えている。この突飛 とも思われる提言に対し，あまり賛成は得られず，む しろ「マニツバモノ」と一笑されたよらである。

しかし，Gaucher と同様突飛な考え方を好む筆者 ${ }^{2}$ は $\mathrm{CO}_{2}-\mathrm{H}_{2}$ の代りに $\mathrm{CO}_{2}-\mathrm{H}_{2} \mathrm{O}$ を取上げた（拙著 「将来のエネルギー問題と石油の成因を考える」参照)。 すなわち Gaucher は地球表面での反応のみを考えた が，浅い地下空洞中で加圧下で反応が和こることも充 分に考えられることから

$$
\begin{aligned}
& \mathrm{CO}_{2}+\mathrm{SiO} \rightarrow \mathrm{CO}+\mathrm{SiO}_{2} \stackrel{\mathrm{SiO}}{\longrightarrow} \mathrm{C}^{*} \\
& \mathrm{H}_{2} \mathrm{O}+\mathrm{SiO} \rightarrow \mathrm{SiO}_{2}+\mathrm{H}_{2}
\end{aligned}
$$

のような反応による，いわゆる Hot carbon と水素と の生成を想定したわけである（SiO は現在市販され， 表面コーチングに活用されている)

ここに生成した Hot carbon は :C:, :C=C: :C $=\mathrm{C}=\mathrm{C}:, \mathrm{C}=\mathrm{C}=\mathrm{C}=\mathrm{C}:$ などの Dicarbene 型をと り，その寿命は $10^{-6} \mathrm{mmHg}$ の真空中で $10^{-6} \mathrm{sec}$ と されているが，水素分子との反応によって容易に岸化 水素化する。そして一次的に生成した炭化水素は後次 の重合, 脱水素, 芳香族化などの反応によって現在の 原油となったと筆者は考えている。な抹，光学的に活 性な窒素化合物の原油中での存在は, 古く石油の有機 成因説と結び付けられてきたが，筆者は植物が出現し た後で，これの分解生成物が二次的に混入されたと解 している。しかしこのような筆者の提案も Gaucher のそれと同様一笑に付された跡がないでもない。

ところで，石油危機を契機として Solar energy に 関する研究が活発となり，特に Solar cell 関係では, 水の光化学分解に対し積極的なメスが加えられ, $\mathrm{CO}_{2}$ $-\mathrm{H}_{2} \mathrm{O}$ からのメタンの生成 $\left(\mathrm{CO}_{2}+\mathrm{H}_{2} \mathrm{O} \stackrel{\mathrm{h} \nu}{\longrightarrow} \mathrm{CH}_{4}+\right.$ $\left.2 \mathrm{O}_{2}\right)$ が可能となってきた。そして，このときの触媒と して $\mathrm{SrTiO}_{3}$ または $\mathrm{SrTiO}_{3}-\mathrm{Pt}$ があげられている。 さて, $\mathrm{CO}_{2}-\mathrm{H}_{2} \mathrm{O}$ からの光化学的メタン生成が可能 であれば当然メタン以上の高級炭化水素の生成も考兄 
られ, また光化学的でなくても, 触媒的方法も充分に 考克られるであろら。筆者は上述のデーターによって 勇気づけられ，ここに石油の成因についての私案を再 提出することとした。

\section{Fischer-Tropsch 石油合成反応之} 植物の同化作用

Fischer-Tropsch 反応の一般式は

$$
\mathrm{CO}+2 \mathrm{H}_{2} \stackrel{-}{-} \stackrel{-}{\longrightarrow} \mathrm{O}_{(}\left(\mathrm{CH}_{2}=\right) \rightarrow \text { ス状, 液状炭化水素 }
$$

触媒は $\mathrm{Ni}, \mathrm{Co}$ または $\mathrm{Fe}$ を主体としたるので, 最 適反応温度は $\mathrm{Ni}, \mathrm{Co}$ のときは180 $210^{\circ} \mathrm{C}$, 鉄のとさ は230〜250 Cである。ただし $\mathrm{Ni}, \mathrm{Co}, \mathrm{Fe}$ 単味では反 応率悪く, 助触媒の使用を必須とする。代表的なもの を例示すると $\mathrm{Ni}-\mathrm{Mn}-\mathrm{Al}_{2} \mathrm{O}_{3}(1: 0.2: 0.1) ; \mathrm{Co}-$ $\mathrm{ThO}_{2}(1: 0.16 \sim 0.18) ; \mathrm{Co}-\mathrm{Cu}-\mathrm{ThO}_{2}(8: 1: 2) ; \mathrm{N}^{\mathrm{i}}$ $-\mathrm{Al}_{2} \mathrm{O}_{3}(1: 0.1) ; \mathrm{Fe}-\mathrm{Cu}-$ alkali $(4: 1: 0.2)$ 。

な扮，上述の助触媒を含む触媒はいずれも混合硝酸 塩の水溶液中にアルカリ, 特に炭酸カリを加えて共 沈させて製造されたもので, ただし $\mathrm{Fe}-\mathrm{Cu}, \mathrm{Co}-\mathrm{Cu}$ 一 $\mathrm{ThO}_{2}$ 系では焼成法る賞用された。ここに特記すべ きは, 沈澱剂によって触媒の活性が異なることで, 炭 酸カリが最もよく, 炭酸ソーダがこれに次ぎ, 苛性ア ルカリ，アンモニアなどでは良結果が得られなかった ことで, 結論として触媒中に残存する微量のアルカリ が触媒の活性を大きく支配するとされている。

一方, 上述の触湈を用い, 且つ同様な反応条件の下 に $\mathrm{CO}-\mathrm{H}_{2}$ の代りに $\mathrm{CO}_{2}-\mathrm{H}_{2}$ を用いると, 高級炭 化水素はほとんど生成せず, 主反応物はメタンとな る。これは $\mathrm{Ni}, \mathrm{Co}, \mathrm{Fe}$ と $\mathrm{CO}$ との反応飞よって $\mathrm{MeC}_{\mathrm{x}}$ のカーバイドを生成し, 水素分子の水素原子へ の触離を抑制するためとされている。

つぎに話題を転じて植物の同化作用について言及し てみる。植物は太陽光線に照射され, クロロフィルの 光増感作用によって $\mathrm{CO}_{2}-\mathrm{H}_{2} \mathrm{O}$ から, 澱粉, 糖類, 蛋白質,アミノ酸, 脂肪酸などを巧みに合成している。 そのときの反応は

$$
\mathrm{CO}_{2}+\mathrm{H}_{2} \mathrm{O}^{18} \stackrel{\mathrm{h} \nu}{\longrightarrow}\left[\mathrm{CO}_{2}+\mathrm{H}_{2}\right]+\mathrm{O}^{18}
$$

このとき $\mathrm{CO}_{2}$ を $\mathrm{O}^{18}$ でラベルしても $\mathrm{O}^{18}$ は外部 に放出されない, 要するに人間並びに生物に必須な酸 素は水の光化学分解によるものである。さて, 中間に 生成した $\left[\mathrm{CO}_{2}+\mathrm{H}_{2}\right]$ の後次反応についてはノーベル 賞を授与された M. Calvin によって詳細検討されて いるが，触媒方面から Ni，Co がこの反応関与して いるのではないかと筆者は考光始めたわけである。

もちろん植物の葉上飞和沙温度は直射日光の下に 最高 $40^{\circ} \mathrm{C}$, ただし温室内では真夏に $60^{\circ} \mathrm{C}$ 位昇ることも
稀でなく，これによる葉害をうけることも少い由であ る。一方 $\mathrm{CO}_{2}-\mathrm{H}_{2}$ 反応济対する $\mathrm{Ni}, \mathrm{Co}$ 触媒の最低 温度は $100^{\circ} \mathrm{C}$ ，ここに注意すべきは植物の同化作用は 触媒反応に比べて反応速度がきわめて遅いことであ る。ただし，植物の葉面上に怙ける反応と触媒反応と を比較すること自体が常識を逸脱していると批判され ることは確かであろう。筆者はこの矛盾を打破するた め, 偶然に入手した蜂蜜中の灰分の分析値を取上げて みたい。

蜂蜜の成分は産地により異なるが, 平均値を示す と $\mathrm{H}_{2} \mathrm{O} 8 \sim 25 \%$, Glucose $30 \sim 42 \%$, Fructose 23〜 $39 \%$, Sucrose 0 4\%, Ash 0.2〜2.5\%である。また 灰分の主成分は一例を示すと $\mathrm{SiO}_{2} 42.6 \%, \mathrm{Fe}_{2} \mathrm{O}_{3}$ $22.6 \%, \mathrm{CaO} 14.3 \%, \mathrm{P}_{2} \mathrm{O}_{5} 9.0 \%, \mathrm{~K}_{2} \mathrm{O} 9.6 \%, \mathrm{MgO}$ 少量である。

一方微量成分については, 結論的には, ありとあら ゆる金属が含まれている。たとえば $\mathrm{Ca}, \mathrm{Mg}, \mathrm{Fe}$, $\mathrm{Mn}, \mathrm{P}, \mathrm{Si}, \mathrm{Cu}, \mathrm{Ni}, \mathrm{Li}, \mathrm{Na}, \mathrm{K}, \mathrm{Ba}, \mathrm{Ag}, \mathrm{pd}, \mathrm{V}$, $\mathrm{U}, \mathrm{Al}, \mathrm{Ir}, \mathrm{Co}, \mathrm{Zn}, \mathrm{As}, \mathrm{Sn}, \mathrm{p}_{\mathrm{t}}, \mathrm{M}_{\mathrm{a}}, \mathrm{Ti}, \mathrm{Cr}, \mathrm{Sr}_{\mathrm{o}}$ ただし, この分析值は1939年に発表されたもので, 現 在の分析装置を用いたときには，恐らく，ほとんどす べての元素が検出されることは確実であろう。

さて, 蜂蜜は花の「メシべ」からの蜜を蜂が運んだ もの。一方花と葉とは一心同体, 換言すれば花は進化 によって葉から変形したものと考觉ると, 花の灰分と 葉のそれとは一応類似していると考えても過言ではあ るまい。るし葉面上に上述の金属が極微量存在すると すれば, Solar concentrator として優れている Zn, $\mathrm{Ni}, \mathrm{Co}, \mathrm{Ti}, \mathrm{Cr}$ などは酸化物の形で, 太陽光線を局 部的に集熱するであろう。その理由は $\mathrm{ZnO}$ は光照射 のよい水を分解し,一方, $\mathrm{Fe}$ 基板上にコーチングされ た Black $\mathrm{Cr}$ (酸化物 $)^{3)}$ まは $\mathrm{Ni}$ 基板上にコーチング とした Co (酸化物) $)^{4)}$ はすでに Solar concentrator されて実用化されているからである。ちなみに $\mathrm{TiO}_{2}$ は $\mathrm{N}_{2} \rightarrow \mathrm{NO}_{\mathrm{x}}$ の酸化力をもっている5)。

さらに, Solar cell 関係の最近の報文にょると， $\mathrm{CdTe}, \mathrm{GaAs}, \mathrm{CdSe}, \mathrm{Si}$ が水の分解性能がきわめて 大で，これに次ぐものとして $\mathrm{GaP}, \mathrm{CdS}$ などがあげ られている。

A) 触媒の Active point と葉面上の Hot spot 触媒方面では Active point または Active partなる 言葉がよく用いられる。たと党ば Ni 触媒によるベンゼ ンの水素添加は100 $150^{\circ} \mathrm{C}$ 付近で行われるが，このと きベンゼン中に触媒毒たとえばチオフェンを入れて， 水素添加がストップしたときの硫化ニッケルの量から 
ベンゼン水素添加能力のある Active point を推算す ると,わずか $0.2 \%$ とれている。

しかし，ベンゼンの水素添加能力がなくなったもの でもカルボニル化合物を水素添加する能力を有し, そ の量は20〜30\%, 残りの, いわゆる大部分硫化ニッケ ルとなった部分は, ここに述べるまでもなく, ニトロ ベンゼンからアニリンの製造に活用されている。

ここにベンゼンの水素添加反応は $\mathrm{Ni}$ 触媒中のわず か0. $2 \%$ に集中されるわけで, 見掛上の反応温度100〜 $150^{\circ} \mathrm{C}$ として局部的には，また瞬間的にはかなりの温 度上昇が扣こったことは間違いないであろら。

ここに，葉面上でも同様な現象が括こっていると筆 者は確信している。凸レンズを用いて太陽光線を集束 し葉を焼切った子供時代の「イタズラ」がこの方面の 証拠固めに大いに役立つと断言できる。

結論的には植物の生長にはクロロフィルの同化作用 と同時に, 葉面上の微量金属 (主として酸化物) が大 きな役割を演じているわけで，ここに筆者の新しい提 案としてご批判を受けたいところである。このように 考えると, 葉面上の微量金属は極少量で充分で, その 量が多くなると，当然葉の焼切れがおこるであろう。

B) Solar concentrator の原理をバラ作りに応用

筆者のバラ作りの経験は相当長く, 20 年以上であ る。化学者である筆者は古い伝統の油粕一骨粉などを 使ら気持になれず，専ら化成肥料の使用に終始した。 もちろん化成肥料が油粕に比べて遜色があり, 一時油 粕使用に転向したこともないではないが，最近では特 に葉面散布法の検討に熱中している。

ここに葉面散布法とは, 葉に化成肥料の希薄水溶液 をスプレーするもので, 尿素の使用から出発したが, 現在では微量ミネラルを含んだものが市販されている が普及率はあまり良くない。

筆者が常用しているヨーダン 2 号の分析值を例示す ると, N 30\%, P 10\%, K 10\%, Mn 0.1\%, B 0.05\%, Fe $0.012 \%, \mathrm{Cu} 0.012 \%, \mathrm{Zn} 0.006 \%$, Mo $0.00012 \%$ 。 ただしこれには $\mathrm{Ca}, \mathrm{Mg}$ が含まれて呿らず, よって 硫酸マグネシウム, 硝酸カルシウムを追加した。また この組成ではバラの生長が思わしくなく,よって尿素 : ヨーダン 2 号=1: 1 を用いることとした。な峦ヨー ゲン 2 号の仕様書には約 300 倍の希釈度で使えとさ礼 ているが, 薬害を恐れ, 2, 000〜4,000倍のきわめて薄い 水溶液として毎日, 朝または夕方にスプレーを続けた。 ところで，新しい考光として0.1〜 1 ppm のニッケ ル，コバルトを硝酸塩の形で添加したところ,すばら しいバラの生長を確認するに至った。
この結果に基き，本年 3 月 8 日からパイロット・テ ストを枚方パークでスタートした。幅 $1 \mathrm{~m}$, 長さ $45 \mathrm{~m}$ に植付けられた約 120 本のバラに対し, 内容 $450 \ell$ のポ リエチレン製タンクを設備し，自動装置タンマーによ って，無人スプレーを実施中である。朝 9 時にスプレ 一開始，約 $40 \mathrm{sec}$ でストップする。毎日の使用量約 $20 \ell$ 。これによって予期の成績を収め得たが，この詳 細については後報に譲りたい。このとき微量の $\mathrm{Ni}, \mathrm{Co}$ は明らかに葉面上で Solar concentrator の役割を演 じたものと確信される。

\section{2. 再び石油の成因を考える}

若かりし頃の Fischer-Tropsch 石油合成法につい ての経験並びに最近の Solar energy に関するレポー トから，筆者の石油成因に関する考方は大きく Gaucher の説を支持する方向に傾きつつある。

30〜40億年前地球が $\mathrm{CO}_{2}-\mathrm{H}_{2}$ 一スチームで包まれ ていたとすれば，また $\mathrm{Ni}, \mathrm{Co}, \mathrm{Fe}$ が地球表面に露出 していたとすれば，Fischer-Tropsch 合成石油反応が おこる公算はきわめて大きい。ただし， Gaucher の 考え方のよらに地表のみでおこったか，また筆者のそ れのよらに地下の空洞で加圧反応が怙こったかは明ら かでない。

Gaucher の考方方に対する常識的な反論は Petroleum rain の点ではないかと考えられる。

また $\mathrm{CO}_{2}-\mathrm{H}_{2}$ を $\mathrm{Ni}, \mathrm{Co}$ ，触媒で反応せしめると メタンのみを生成することから

$$
\mathrm{CO}_{2}+\mathrm{H}_{2} \rightleftarrows \mathrm{CO}+\mathrm{H}_{2} \mathrm{O}
$$

の shift 反応を考えざるを得ない。また等 $\mathrm{CO}-\mathrm{H}_{2}$ で も水素の分圧が大きいときには大部分メタンとなる。 な拈天然ガ ス井に拈いて $\mathrm{CO}_{2}$ 多量の混在は $\mathrm{CO}_{2}$ $\mathrm{H}_{2}$ の反応によるものであろら。

このように考えてくると, Gaucher の提言する地 表説よりも地下の空洞中で加圧反応が拈こったとする 方が Petroleum rain に対する反論を解消し, また現 在の油井の構造から考劣ても妥当ではないかと考えら れる。すなわち，天贸地変によって空洞を生成し，同 時に地表上の $\mathrm{CO}_{2}-\mathrm{H}_{2}$ 一スチームはその中に吸込ま れる。後次の反応は Fischer-Tropsch 反応によるか, または筆者の考えているよらに $\mathrm{SiO}$ にる

$$
\begin{aligned}
& \mathrm{CO}_{2}+\mathrm{SiO} \rightarrow \mathrm{CO}+\mathrm{SiO}_{2} \stackrel{\mathrm{SiO}}{\longrightarrow} \mathrm{C} \\
& \mathrm{H}_{2} \mathrm{O}+\mathrm{SiO} \rightarrow \mathrm{H}_{2}+\mathrm{SiO}_{2}
\end{aligned}
$$

のような還元反応が泡こるかは Nobody knows の分 野であろう。結論的には石油の Precursor は $\mathrm{CO}_{2}$ $\mathrm{H}_{2} \mathrm{O}$ あるいは $\mathrm{CO}_{2}-\mathrm{H}_{2}$ といらこととなる。

A）有機成因説 
上述のように 30 ～40億年前における石油の生成をあ る程度肯定したが，従来主張されていた石油有機成因 説に対する私見を述べてみたい。

地表の温度が $100^{\circ} \mathrm{C}$ 付近になったのは約 20 億年前と され，ここにアミバーのような下等生物の創造が始ま る。これ北要な酸素は水の光化学分解によると推定 されるが，他の因子る充分侤克る必要がある。さら に地表の温度が $40^{\circ} \mathrm{C}$ 以下になれば, ここに植物が出現 してくる。同時他梂を取巻くスチームは凝縮して 海，湖または河川となる。また植物の同化作用によっ て生物の生存に必須な酸素が充分飞供給される時代を 迎えることとなる。

さて, 植物が太陽光線を吸収して,いわゆる Biomass となる収率は理論值の $12.5 \%$ に対し, 天然ゴムの木 $0.2 \%$, 蔗糖 $1.2 \%$, 一方海藻は以外飞高く $2.0 \%$ せ 界全体の平均 $0.2 \%$ とさているき。海藻の光量子収 率 $2.0 \%$, 怙そらく水藻も同様であ万弓。その大きな 原因は海水中ならびに藻表面に捺ける Solar concentrater の存在によると解せられる。ここに, 従来のプ ランクトン源説を拡大解釈すれば, 藻一プランクトン から石油ができたと解してもたいした矛盾はないであ ろう。

筆者は30～40億年前の石油生成時代を一次石油生成 時期, 上述の藻一プランクトンからのそれを二次石油 生成時期と致したい。このように考㝋てくると，現在 でも石油の生成は続いているのではあるまいか。この 考方方でも, Precursor は一次と同様 $\mathrm{CO}_{2}-\mathrm{H}_{2} \mathrm{O}$ で あると再記して扮きたい。

B) $\mathrm{C}_{1}$ 化学と $\mathrm{CO}_{2}-\mathrm{H}_{2} \mathrm{O}$ との相関性

溶融した鉄, アルミニウム上に水を滴下すると爆発 が扣こる。最近怙こったアルミニウム加工工場での火 災事故は消防による散水の危険性を如実に示した。明 らかに水の分解による水素の発生を示するのである。 他の金属でも類似の反応が特こる可能性が大きい。30 〜40億年前に, 地下の空洞でこのような反応がおこっ たかどらか?

さて, $\mathrm{CO}_{2}-\mathrm{H}_{2}$ から合成できる $\mathrm{C}_{1}$ 化学の主原料 はメタノールであろう。現に BASF では石炭からCO - $\mathrm{H}_{2}$ 引いてはメタノールを合成し,ついでメタノール からジメチルエーテルを中間体としてエチレン，プロ ピレン製造のパイロット・テストに乗出している。

箻者も Fischer-Tropsch 法用触媒の存在の下にメ タノールから固体のポリメチレンを合成したことを見 い出している。植物の同化作用と同様, 集束された太 陽光線によって $\mathrm{CO}_{2}-\mathrm{H}_{2} \mathrm{O}$ から $\mathrm{CO}_{2}-\mathrm{H}_{2}$ を製造す
ることは不可能ではあるまい。 $\mathrm{CO}_{2}-\mathrm{H}_{2} \mathrm{O}$ からの石油 合成のモデル反応が出現することを期待したいるので ある。

\section{3. 代替燃料としてのエタノール7)}

石油危機を契機としてニーカリまで飛び出したが， 石油を造り得る植物はゴムの木を初めとして，世界に 2,000 種を数えるといわれている。

さて，代替然料として最近大きくクローズ・アップ されているのは, 何といってもェタノールであろう。 ガソリンに30\%位までエタノールが混和された燃料 Gasohol（アルコール業者間では一名 Gasahol）の実 用化が特にブラジル政府の積極的な保護政策によって 世界の注目を集めつつある。またエタノールからのエ チレン（年間 146,000 t ）アセトアルデヒド（年間 94, $560 \mathrm{t}$ ), さらにオクタノール, ブタジェンなどの 石油化学製品の生産も外国資本の導入によって活発化 しつつある。

さて，このときの原料はブラジルで過剩気味の蔗 種, この光量子収率は前述のように $1.2 \%$, カロリー ベースで計算するとガソリンの約 5 倍のコスト高であ るとは，米国石油業界からの報道である。

これが正しいかどうかは別として $1.2 \%$ 収率を何ら かの方法によって，たとえば $2 \%$ と上昇すれば，エ タノール燃料むかなり経済性を増大するであるら。蔗 糖の増産のみならず, 一般食料のそれは, 今後の代替 燃料としての Biomass の価値を大きく増大するわけ で, 今後の大きな研究課題であろう。

\section{4.むすび}

以上, Fischer-Tropsch 法に関する若かりし頃の経 験を基として, また植物の同化作用と結び付けて, 石 油の成因について，再び私案を提出した。そしてその Precursor $\mathrm{CO}_{2}-\mathrm{H}_{2} \mathrm{O}$ と結論した。

この私案の重要なとントとなったのは, 筆者の庭に 植えられている 200 本余のバラ作りの経験で, 20年以 上の Heavy chemical test に耐えて毎年美しい花を 咲かせてくれたことに対し感謝の気持で一杯であるこ とを終記させて頂きたい。

\section{文献}

1) L.P. Gaucher, Chem.tech., Aug. 471 (1972)

2）堤，燃協誌，53，306（昭49）

3) J. McKelvey, ES \& T., 13, 918 (1979)

4) Chem. tech., April 252 (1980)

5) $C \& E N .$, Aug. 6, 19 (1979)

6) Chem.tech., July 434 (1976)

7) $C \& E N$., Aug. 6, 15 (1979) 